Original Research Paper

\title{
Ways of Increasing Seed Germination of Sweet Clover and Methods of Reducing the Amount of Coumarin in the Leaf-Stem Mass
}

\author{
${ }^{1}$ Marden Ersainovich Baidalin, ${ }^{1}$ Igilik Imangalievich Zhumagulov, \\ ${ }^{1}$ Ermek Ualikhanovich Sagalbekov and ${ }^{2}$ Ualikhan Molgazhdarovich Sagalbekov \\ ${ }^{1}$ S. Seifullin Kazakh Agrotechnical University, Republic of Kazakhstan, 010000 Astana, Pobeda Avenue, 62, Kazakhstan \\ ${ }^{2}$ Sh. Ualikhanov Kokshetau State University, Republic of Kazakhstan, 020000, Kokshetau, Abay Street, 76, Kazakhstan
}

Article history

Received: 07-03-2017

Revised: 31-05-2017

Accepted: 16-06-2017

Corresponding Author: Marden Ersainovich Baidalin

S. Seifullin Kazakh

Agrotechnical University,

Republic of Kazakhstan,

010000 Astana, Pobeda

Avenue, 62, Kazakhstan

Email: marden_0887@mail.ru
Abstract: The article presents the results of laboratory and field experiments on studying the influence of ways of presowing seed treatment and methods of reducing the amount of coumarin on yield and forage quality of sweet clover in the conditions of Northern Kazakhstan. The aim of the research is to study and to prove the effective way of presowing treatment of seeds and a method of decreasing the content of coumarin in order to increase the productivity and to improve the quality of clover forage. The experimental station of the North-Kazakhstan SRI of agriculture in 2015-2016 was conducted pursuant to the solution of tasks. In our experiments, it was shown that the proposed method of presowing treatment of sweet clover seeds improves the laboratory germination from 65.2 to $99.0 \%$ and the field germination from 33.1 to $72.8 \%$. When applying the technique of reducing the content of coumarin, its content in the green mass of clover was $1.14 \%$, in the hay dried at a temperature of $20^{\circ} \mathrm{C}-0.65 \%$ and at a temperature of $60^{\circ} \mathrm{C}-0.48 \%$. The coumarin content decreased two times. The protein content of the hay dried at a temperature of $20^{\circ} \mathrm{C}$ was $13.2 \%$, at a temperature of $60^{\circ} \mathrm{C}-15.1 \%$. The content of fodder units at a temperature of $20^{\circ} \mathrm{C}$ was $0.39 \%$, at a temperature of $60^{\circ} \mathrm{C}-0.47 \%$. Based on the research results on studying ways, which increase seed germination and methods of reducing the amount of coumarin in sweet clover, the way of presowing treatment of sweet clover seeds, which increases seed germination almost by $100 \%$ and an effective technique of making sweet clover hay, which reduces the coumarin content to safe limits for animals, as well as increases the fodder value of sweet clover hay, were developed and proposed for the production. The method of increasing seed germination of sweet clover is simple in the technical performance and not costly from an economic point of view, which is performed by soaking the seeds of sweet clover in water for $24 \mathrm{~h}$, with further drying and separating the swollen soft seeds on a sieve with a diameter of $2.5-3 \mathrm{~mm}$ and the process ends by scarification. The essence of the method of reducing the coumarin amount is that sweet clover, in connection with the content of antinutrient- coumarinin the vegetative mass, should not be fed in the green form and hay making should be fulfilled by the method of active aeration at a temperature of $60^{\circ} \mathrm{C}$. Along with the decrease in the content of coumarin, the quality indicators of hay increase. Hay, dried by active aeration at a temperature of $60^{\circ} \mathrm{C}$, is bright-green, well-foliated and has a pleasant smell.

Keywords: Clover, Seeds, Seed Hardness, Scarification, Swelling, Forage Quality, Coumarin, Foliage, Fodder Units 


\section{Introduction}

The global problem in the world is that the Earth's population by 2050 will grow to 2.5 billion, an increase of $34 \%$ and will reach 9.1 billion. To feed so many people it is necessary to double food production (Makkar et al., 2014). To ensure the production of large amounts of food products with the lowest cost is impossible without the development of innovative technologies. The strategy for the development of the cost-effective food sector is based on the combination of two fundamental factors: High animal productivity through the use of high-protein feeds and a low-cost system of feed production.

An important role in increasing the production of protein-rich forages in the steppe zone of the Republic of Kazakhstan belongs to the legume grasses-lucerne, sainfoin and clover. In comparison with gramineous plants, legume crops are characterized by high content of protein and amino acids (PDACRK, 2012). In Northern Kazakhstan, the cheapest protein is obtained by sowing of perennial legumes, including clover as one of the promising forage crops.

Clover belongs to the legume family (Fabaceae) and comprises 19 annual and biennial species. All species originated from Eurasia and North Africa (Aboel-Atta, 2009). In the wild world, clover provides food for various birds and mammals. The stems and leaves can be a significant part of the diet of elk, deer and antelope (Sullivan, 1992). Sweet clover has high yields of seed and hay, resistant to extreme environmental conditions such as drought, cold and soil salinity compared to other legume forage crops (Rogers et al., 2008; Sherif, 2009). Sweet clover grows well in regions where the annual rainfall is not more than nine inches, but the optimum conditions for it are from 12 to 20 inches of annual precipitation. Clover with its fast growth and unpretentiousness is effectively used in reclamation plantings. In addition, it restores the soil after fire and other degraded soils (Thornburg, 1981). Sweet clover, like other legumes, increases the nitrogen in poor soils. Pivotal root system increases aeration and water absorption of the soil. Clover as an important forage crop and its medicinal value causes an increased interest, since plants of sweet clover contain coumarin-a substance that is widely used in medicine (Cong et al., 2012). The scientific name for clover derives from the Latin word Mel (honey) and Lotus, the genus of dicotyledonous plants of the legume family. It is popular specie for honey production. The flowers of sweet clover are attractive for bees and butterflies (Ogle et al., 2007).

Seeds can remain viable for up to 20 years, waiting for favorable conditions for the growth and that is a problem in subsequent crops (Ghaderi-Far et al., 2010). At the cultivation of sweet clover, significant thinning of the grass is often observed. The low field germination of sweet clover is a consequence of one of the following reasons or their complex: (1) Excessively deep planting; (2) late sowing; (3) the decay of later germinating seeds, (4) seed hardness. In the seed farming, the term "seed hardness" refers to the inability of seeds to swell in water for a certain time (according to GOST 12038-66, for 10 days at a temperature of $20^{\circ} \mathrm{C}$ ). As a result, seeds do not germinate without special processing techniques. Seeds of sweet clover without special techniques of scarification did not germinate (Poptsov, 1976). Artificial methods of mitigating of impervious seed include soaking it in acid or solvent, freezing, heating and radiation therapy (Rolston, 1978). The problem of quality control and improvement of germination of clover seed is always rising during the scarification. The quality of scarification is determined by the swelling of seeds in water. If different processing methods of scarification are a little bit developed, at the same time the techniques of quality control of performance of these works with the aim of maximizing of seed germination are not well developed.

There are various ways of economic use of clover, the main one- for green forage, hay and haylage. Clover has good enough taste and cattle, sheep and horses readily eat it. The National Academy of Sciences of USA (1971) gives the following nutritional values of sweet clover: The content of crude protein is $15 \%$; digestible protein- $10.2 \%$ (by cattle), $10.5 \%$ (by horses) and $10.6 \%$ (by sheep) (NAS, 1971). Also, clover gives large yields of hay and the costs for feed production from sweet clover are not high. Clover hay is very valuable, if you comply with the procurement technology, it is comparable to alfalfa hay. However, this is excluded by such a negative biological feature of sweet clover as a forage plant as the maintenance in the leaf-stem mass of the coumaringlucoside. If forage from clover begins the process of decay, it is less eaten due to its bitter taste, due to the fact that the tissues of the plant contain coumarin which is converted to dicoumarin. When eating clover, bloating is manifested in animals, but compared to alfalfa and clover that is less significant. The likelihood of bloating in animals in eating of clover can be avoided by converting green weight to dry food, either in addition to clover to provide a sufficient amount of water and salt in the diet. Because of the risk of bleeding in cattle when eating clover, the green mass should be dried to $13-14 \%$ of moisture content (Meyer, 2005; Baldridge and Lohmiller, 1990). Because of the content of toxic substances (coumarin), fresh sweet clover is used to feed animals in extremely limited quantities. Its greatest amounts accumulate in plants during the flowering period (1.2\%). According to E. Frener, $50 \mathrm{~g}$ of coumarin kill a horse and $5 \mathrm{~g}$ kill a sheep. A dose of 25 
$\mathrm{g}$ is dangerous for horses and cattle. To harvest sweet clover for hay is necessary when the period of budding is $90 \%$. By the end of the flowering stage, the yield and quality of hay are reduced.

The clover contains a harmless substance lactone of coumarinic acid-coumarin $\left(\mathrm{C}_{9} \mathrm{H}_{6} \mathrm{O}_{2}\right)$. However, at rotting and molding it turns into poisonous dicoumarin $\left(\mathrm{C}_{19} \mathrm{H}_{12} \mathrm{O}_{6}\right)$. Dicoumarin is an anticoagulant which causes hemorrhaging in cattle and can lead to death. Animals will experience difficulties of clotting and they can die from blood loss due to small external or internal damage. Sheep and horses are less prone to this disease because they are more selective when eating feed (Schipper, 1999). Dicoumarol (dicoumarin) belongs to the group of anticoagulants of blood, has a specific lemon smell and can cause poisoning and death of animals (Andreeva, 1956).

The analysis of special scientific literature and patent search have revealed that in Kazakhstan due to seed hardness and the content of coumarin in sweet clover a focus for the study of ways of seed hardness removing and reducing the amount of coumarin in sweet clover forage was not carried out. To date, various methods for the determination of coumarin content have been developed, the selection of non-coumarin forms of sweet clover has been conducted and the biology of seed hardness has not been practically studied.

The aim of the research is to study and argument the effective way of presowing treatment of seeds and to receive the lower coumarin content for increasing the productivity and improving the quality of forage clover.

\section{Materials and Methods}

The research was carried out in 2015-2016 in the experimental field of LLP "North-Kazakhstan SRI of Agriculture" (village Chaglinka). The soil of experimental plot is ordinary chernozem. The predecessor is bare fallow; tillage was carried out according to the zonal technology. Seeding is early spring (in early May), uncoated. Taking into the consideration the area of plots- $25 \mathrm{~m}^{2}$, it was repeated 3 times. The placement of options was randomized. In the research, yellow sweet clover was used, a promising variety "Kokshetauskii 14".

The laboratory germination of seeds was determined on Petri dishes in 6-fold replication of 100 seeds in each (GOST 12038-84).

The account of the plant density after germination and before harvesting and preservation of plants were carried out at fixed sites in two non-adjacent replicates according to the variants of experience.

Observations and surveys were conducted according to the methodology of the All-Russian Research Institute of Fodder (VNII, 1985).
In the accredited agrochemical laboratory, the content of total Kejeldahl nitrogen was determined, crude protein - by the calculation method using the coefficient of 6.25; ash - according to GOST 13979.6-69; crude fiber - according to GOST 13496.2-91; crude fat -according to GOST $13496.15-7$. The mathematical processing of research results was carried out by common techniques (Dospekhov, 1973). The allocation in fodder units was carried out using the digestibility coefficients according to Tomme (1964). The obtained research results were processed by statistical methods (ANOVA); the IBM SPSS 20.0 software and Excel program were used for calculations.

To determine the coumarin content in sweet clover, a quantitative method for the determination of coumarin according to the method of G.K. Nikonov was used. This method allows determining both the percentage and the mass of coumarins. According to G.K. Nikonov's method, $25 \mathrm{~g}$ of the finely ground material (stems, leaves) is weighed and $250 \mathrm{~cm}^{3}$ of chloroform is extracted by macerating for $24 \mathrm{~h}$. The weight and thus the amount of solvent can be reduced. The solution is filtered and $200 \mathrm{~cm}^{3}$ of it is distilled off to dryness in the flask. $20 \mathrm{~cm}^{3}$ of $10 \% \mathrm{NaOH}$ solution is added to the residue, is heated in water bath for $5 \mathrm{~min}$, the liquid is transferred to a separating funnel and the coumarins are extracted with chloroform by portions of $25 \mathrm{~cm}^{3}$ four times. The remaining alkaline solution is acidified with $20 \%$ sulfuric acid solution and is extracted with chloroform portions of $25 \mathrm{~cm}^{3} 3-6$ times (sample for dry residue). The chloroform extracts are combined, are shaken with $20 \mathrm{~cm}^{3}$ of $5 \% \mathrm{Na}_{2} \mathrm{CO}_{3}$ solution in the separating funnel, then with $20 \mathrm{~cm}^{3}$ of water and are dried with anhydrous sodium sulfate. The filtered solution is distilled off in the weighed flask, the residue is dried at $70^{\circ} \mathrm{C}$ to the fixed weight. By the difference between the mass of an empty beaker and a beaker with the coumarins, the content of coumarins in $25 \mathrm{~g}$ was identified.

\section{Results}

For the conclusion about the necessity of scarification, any batch of seed must undergo a highly sophisticated analysis carried out in seed laboratories. The quality of scarification is determined by the swelling of the seeds in water.

Experiments have shown that if soaking the seeds of sweet clover in water all soft scarified seeds swell and increase in volume 2-2.5 times. A sample of scarified seeds, totally - 100 pieces, are soaked in 6-fold replication for $24 \mathrm{~h}$ in water. Then, the amount of soft (swollen) and solid (remain in the water without modification) seeds was counted (Table 1). 
Swelling is the first stage of seed germination, which lasts from clover up to 18-24 h. The termination of hydration and drying of seeds at this stage, till the growth of cells of the germ has not yet begun, leads to a decrease in germination and seed vigor (Sagalbekov et al., 1987).

This is the same method that was used for separating of soft scarified seeds from hard, requiring the repeated scarification.

To do this, after soaking the seeds in water and swelling, the soft fraction is separated on a sieve with a size of 2.5-3 mm from the solid fraction, which did not change their size and easily passed through the sieve. After drying, they are exposed to re-scarification. This allows reaching $90 \%$ of sown seeds germination. Soft seeds after drying are used for planting (Table 2).

The need in re-scarification is due to the fact that with longer single mode seed treatment, injury of seed increases to $10-15 \%$.

The experiments have shown that soaking and drying seeds during the day significantly increased the germination and vigor compared to the control of scarified seeds that have not been socked (Table 3).

Pre-moistened seeds begun to germinate on the second day and already after 4 days $95.2 \%$ of seed sprouted, while in the control variant-only $32.4 \%$. Even a month-long observance of the seeds subjected to this integrated treatment did not affect the performance of laboratory germination, which proved to be as effective as the two-week gap of scarification with subsequent dipping and drying.

After 10 days, in the experimental variant (scarification + moisture) $99.0 \%$ of seed were sprouted, while in the control variant only $84.2 \%$. It is obvious that soaking scarified seeds for up to $24 \mathrm{~h}$ contributes to the activation of the enzymatic system of seeds, but does not affect the growth phase of the seed. Subsequent drying does not reduces seed germination, but even slightly increases the germinating energy of seeds that provides the reception of amicable shoots. The results of the effectiveness of this method are given in Table 4.

Table 1. Amount of swollen and hard seeds of clover depending on the method of scarification (in average over 2015-2016 years)

\begin{tabular}{|c|c|c|c|}
\hline \multirow[b]{2}{*}{ No. } & \multirow[b]{2}{*}{ The method of scarification } & \multicolumn{2}{|c|}{ The amount of seeds } \\
\hline & & Swollen & Solid \\
\hline 1 & No scarification (control) & $17 \pm 1.70$ & $83 \pm 1,33$ \\
\hline 2 & Clever grater & $67 \pm 0.92$ & $30 \pm 2.00$ \\
\hline 3 & Breeding grind (converted) & $90 \pm 1.00$ & $8 \pm 2.72$ \\
\hline 4 & Manual scarification & $96 \pm 1.22$ & $4 \pm 1.40$ \\
\hline $\mathrm{LSD}_{0}$ & & 1.88 & 2.49 \\
\hline
\end{tabular}

Table 2. Quality of scarification of clover seeds (in average over 2015-2016 years)

\begin{tabular}{lllll}
\hline & & \multicolumn{2}{l}{ The amount of seeds, pieces } & \\
The method of scarification & The number of scarification & Swollen & Solid & Impaired (not viable) \\
\hline Manual scarification & 1 & $96 \pm 1.22$ & $4 \pm 1.40$ & $0 \pm 0.00$ \\
Breeding grind (converted) & 2 & $90 \pm 1.00$ & $8 \pm 2.72$ & $2 \pm 1.73$ \\
Clever grater & 3 & $67 \pm 0.92$ & $17 \pm 1.70$ & $16 \pm 1.71$ \\
LSD $_{05}$ & & 1.99 & 2.57 & 2.82 \\
\hline
\end{tabular}

Table 3. Seed vigor and laboratory seed germination (for 2015-2016 years)

\begin{tabular}{lll}
\hline $\begin{array}{l}\text { The method of preparing } \\
\text { seeds for sowing }\end{array}$ & $\begin{array}{l}\text { The germinating energy } \\
\text { in } \% \text { after } 4 \text { days }\end{array}$ & $\begin{array}{l}\text { Laboratory germination } \\
\text { in \% after } 10 \text { days }\end{array}$ \\
\hline Scarification (without soaking) & $32.4 \pm 2.8$ & $84.2 \pm 0.57$ \\
Scarification + hydration & $95.2 \pm 1.53$ & $99.0 \pm 1.00$ \\
LSD $_{05}$ & 4.13 & 1.85 \\
\hline
\end{tabular}

Table 4. Influence of the method of seed preparation for clover germination (average over 2015-2016 years)

\begin{tabular}{lll}
\hline & Seed germination, $\%$ & Field \\
The method of preparing seeds for sowing & - Laboratory $^{-}$ & $33.1 \pm 1.00$ \\
\hline Clever grater & $65.2 \pm 0.58$ & $72.8 \pm 0.57$ \\
Breeding grind + moisture & $99.0 \pm 1.00$ & 1.85 \\
LSD $_{05}$ & 1.85 & \\
\hline
\end{tabular}


Thus, the laboratory germination of clover seed prepared for sowing by this method increased from 65.2 to $99.0 \%$ and field germination rate increased from 33.1 to $72.8 \%$.

The content of the coumarin is a negative figure, which has a clover. In order to reduce or eliminate the content of this material, for the first it is necessary to learn the methods of determination of coumarin in the leaf-stem mass. There are many methods for the determination of coumarin-micro-chemical, calorimetric, fluorometric, gas chromatography method and others. In our studies, we used the method of G.K. Nikonova. In clover, coumarinwas detected in all parts (Table 5).

The essence of this method lies in the fact that the prepared samples of clover are immersed for 1-2 min in a solution of iodine in potassium iodide. Samples containing coumarin in concentrations greater than $1 \%$ are colored in magenta color, $0.9-0.5 \%$ in pink, if less than $0.1 \%$ they do not change their color. The design is very simple and not expensive; it allows an express method of determining the content of coumarin.

In studies of Andreeva (1956), it was found that the content of coumarin is reduced when clover is dried compared with its content in the green mass. It is known that during drying of clover in the shade as a result of more complete hydrolysis of the glucoside, the content of coumarin is reduced by $52-78 \%$ of the original amount. These facts of coumarin reducing when sweet clover is dried are observed in the studies of Berke and Dornerri (1955). Later, the same pattern was observed in the experiments of Stuezynski and Mangalska (1959) and Deineko (1983). In our experiments, it was found that the content of coumarin when dried clover is reduced compared with its content in the green mass (Table 6).

The reason for the decreasing in coumarin content in dried clover is the cleavage of coumaringlucosides. The evaporation of moisture causes the release of coumarin from beveled dry plants and its reduction in the hay.

The proposed method of harvesting forage from clover is based on these experimental data.

The essence of it is that clover in connection with the content of coumarin in the vegetative mass should not be fed in the green form and hay making should be fulfilled according to the method of aeration, then the content of coumarin is reduced for more than 2 times.

The results showed that the most effective method of reducing the concentration of coumarin was hay made by the method of active aeration at a temperature of $60^{\circ} \mathrm{C}$ (Table 7).

When the hay is made by the method of aeration at a temperature of $60^{\circ} \mathrm{C}$ in comparison with the traditional technology, the content of coumarin is reduced from 0.65 to $0.48 \%$, while the protein content increased from 13.2 to $15.1 \%$, mainly due to preservation of the leaves and better foliage, the collecting of fodder units increases from 0.39 to $0.47 \%$.

Table 5. Content of coumarin in different organs of plants of sweet clover (average over 2015-2016 years)

\begin{tabular}{ll}
\hline Plant organs & The content of coumarin, \% in absolutely dry substance \\
\hline Leaves (young) & 1.55 \\
Leaves (lower layer) & 0.72 \\
Stems & 0.34 \\
Flowers & 1.61 \\
Seeds & 0.27 \\
Roots & 0.09 \\
\hline
\end{tabular}

Table 6. Content of coumarin in the leaf-stem mass of clover by types of feed (in average for 2015-2016 years)

\begin{tabular}{ll} 
Type of feed & The content of coumarin, \% \\
\hline Green mass & $1.14 \pm 0.53$ \\
Haythat was dried at a temperature of $20^{\circ} \mathrm{C}$ & $0.65 \pm 0.50$ \\
Haythat was dried at a temperature of $60^{\circ} \mathrm{C}$ & $0.48 \pm 0.30$ \\
$\mathrm{LSD}_{05}$ & 0.09 \\
\hline
\end{tabular}

Table 7. Effect of different methods of making hay from clover on forage quality and yield (in average for 2015-2016 years) Content in $1 \mathrm{~kg}$ of dry matter, $\%$

\begin{tabular}{llllll}
\hline & \multicolumn{2}{l}{ Content in $1 \mathrm{~kg}$ of dry matter, \% } & & \\
& $-\mathrm{y}$ & & \\
Feed & Coumarin & Protein & Nutritional units & The foliage, \% & Yield of hay, c/ha \\
\hline Hay (traditional technology) & $0.65 \pm 0.50$ & $13.20 \pm 0.64$ & $0.39 \pm 0.97$ & $36.80 \pm 0.37$ & $27.6 \pm 1.00$ \\
Hay (aeration) & $0.48 \pm 0.30$ & $15.10 \pm 1.19$ & $0.47 \pm 1.44$ & $50.70 \pm 0.91$ & $30.3 \pm 1.13$ \\
LSD $_{05}$ & & & & 2.11 & \\
\hline
\end{tabular}


Table 8. Effect of different methods of hay making from clover on the chemical composition (average 2015-2016)

Chemical composition, $\%$

\begin{tabular}{llllll} 
Feed & Ash & Crude protein & Fiber & Fat & Nitrogen-free extractive substances \\
\hline Hay (traditional technology) & 6.9 & 13.6 & 36.6 & 2.6 & 40.3 \\
Hay (aeration) & 9.9 & 15.5 & 29.5 & 4.0 & 41.1 \\
\hline
\end{tabular}

Table 9. Economic efficiency of various technologies of making sweet clover hay

\begin{tabular}{lll}
\hline Indicator & Traditional technology & Hay dried at a temperature of $60^{\circ} \mathrm{C}$ \\
\hline Yield, c/ha & 27.6 & 30.3 \\
Collecting of fodder units, c/ha & 10.2 & 16.9 \\
Costs per 1 ha, tenge & 14,400 & 15,200 \\
Prime cost of 1 c, tenge & 521 & 501 \\
Selling price/c, tenge & 1,500 & 1,500 \\
Cost of the whole production per 1 ha, tenge & 41,400 & 45,450 \\
Profit per 1 ha, tenge & 27,000 & 30,250 \\
Economic effect per 1 ha, tenge & - & 3,250 \\
\hline
\end{tabular}

Along with the improvement of quality, the foliage hay in the procurement with active aeration at $60^{\circ} \mathrm{C}$ increases from 36.8 to $50.7 \%$ due to the reduction of losses of forage mass at stationary keeping, compared to keeping in the field.

In the process of drying grass for hay in plants there are very complex biochemical processes that are accompanied with the transformation and partial loss of organic matter. Cell death is mediated due to irreversible changes in the intracellular structure when reducing the moisture content of the plant up to $40-50 \%$.

Biochemical processes occurring in plants during drying of grass (from mowing to programmed cell death) are followed by the transformation and loss of carbohydrates and at the same time by the proteolysis of proteins; as a result, the amount of amides in the grass increases, mainly the amino acids and acid amides and at a deeper flow of processes - the ammonia and organic acids.

The transformation of substances in plants after death of cells is called autolysis. During autolysis there is a further decomposition of substances, accompanied by loss mainly of nitrogen. The destruction of amino acids leads to a reduction in the amount of crude protein and to a decrease in its biological value. The humidity of the plants in this period decreases as a result of evaporation of water from the surface of dead plant tissue. To minimize nutrient losses, the drying of the grass in the period of autolysis should be fast. When drying, herbs in the result of biochemical processes lose from 5 to $10 \%$ of organic matter and the nutrient digestibility is reduced. Under adverse conditions of drying, these losses increase 2-3 times.

To reduce the time of drying of the green mass in the field and thereby to decrease the mechanical losses and losses from biochemical processes, the microbial growth and leaching of soluble nutrients by rains, active (forced)aeration of the mass at a temperature of $60^{\circ} \mathrm{C}$ is used, which is stacked in storage much earlier than it reaches the moisture content of the finished hay.
To identify the fodder value, the comparative estimation of the chemical composition of sweet clover hay made at different temperatures was carried out (Table 8).

The table data shows that the nutrient value in hay making method of active aeration at a temperature of $60^{\circ} \mathrm{C}$ in comparison with the traditional technology is much higher, it has less fiber- $29.5 \%$ and in dried hay at a temperature of $20^{\circ} \mathrm{C}-36.6 \%$, on all counts (ash, crude protein, fat, BES) hay made by the proposed method exceeds hay made by the traditional technology. Hay dried according to this method is bright green, wellfoliated and has a pleasant smell; it is much richer in protein than hay dried in the usual way.

The calculation of economic efficiency has shown that only by the yield data the recommended way of making sweet clover hay by the method of active aeration at a temperature of $60^{\circ} \mathrm{C}$; besides, the main task of reducing the amount of coumarinin the forage mass provides an economic effect $-3,250$ tenge per 1 ha (Table 9).

\section{Discussion}

By the obtained data on the study of sweet clover seed hardness and the content of coumarin in it, the following conclusions can be drawn:

- Seed hardness of sweet clover is $80-90 \%$

- The need for re-scarification is due to the fact that with longer single seed treatment mode, injury of seeds increases by $10-15 \%$

- The quality of scarification is determined by swelling of seeds in water

- Swelling is the first stage of seed germination which lasts in sweet clover to $18-24 \mathrm{~h}$. The termination of moistening and drying of seeds at this stage, until the growth of germ cells has started, doesn't lead to a decrease in germination and seed vigor

- The pre-moistened seeds start to germinate on the second day 
- Coumarin is contained in all plant organs of sweet clover

- The reason for coumarin reducing when sweet clover is dried is the cleavage of coumaringlucosides

In practice there are many artificial ways of removing sweet clover seed hardness: Soaking seeds in sulfuric acid, temperature effects, radiotherapy, machining, etc. Of the above methods scarification was used in the studies because this method is affordable, safe and less costly from an economic point of view. Thus, for example, the use of sulfuric acid is not safe and overexposing seeds in acid leads to a decrease in seed germination.

The proposed method of presowing treatment of seeds by soaking scarified seeds for up to $24 \mathrm{~h}$ contributes to the activation of seed enzymatic systems but does not affect the growth phases of seeds. Subsequent drying doesn't only reduce but even slightly increases seed vigor and germination.

Due to the proposed method of presowing treatment of seeds, the laboratory germination increases to a maximum; based on this data, in further studies the effect of different growth regulators to increase the field germination of sweet clover will be examined.

When studying the effect of the temperature regime on the reduction of coumarin content in the green mass, there is a tendency that the increase in temperature directly affects the coumarin reduction. We have proposed the method of making sweet clover hay which reduces the coumarin content to safe limits. The essence of it is that sweet clover, because of the coumarin content in the vegetative mass, should not be fed in the green form and hay making should be fulfilled by the method of active aeration at a temperature of $60^{\circ} \mathrm{C}$.

To reduce the coumarin content to a minimum the further studies will be aimed at increasing the temperature regime while conserving sweet clover forage. The experiment in temperature effects over $100^{\circ} \mathrm{C}$ is planned. The essence of it is that at AVM-0.4 aggregates, in which the temperature of the thermal reagent is over $100^{\circ} \mathrm{C}$, of the green mass of sweet clover pelleted forage will be made.

\section{Conclusion}

Based on the experimental data on studying ways of seed hardness removing and methods of reducing the amount of coumarin in sweet clover, the method of presowing treatment of sweet clover seeds, which increases seed germination almost by $100 \%$ and enables to remove sweet clover seed hardness, was developed and proposed. Also, the authors proposed the method of making sweet clover hay, which reduces the coumarin content more than two times, thereby improving the quality indicators of hay.

\section{Acknowledgment}

We would like to thank all the persons who helped us during our research.

\section{Author's Contributions}

Marden Ersainovich Baidalin: Performed all field and laboratory experiments, conducted literature review, analyzed and interpreted obtained data.

Igilik Imangalievich Zhumagulov: Coordinated the research programme and methods.

Ermek Ualikhanovich Sagalbekov: Consulted research works.

Ualikhan Molgazhdarovich Sagalbekov: Designed research plan and methods.

\section{Ethics}

This article is original and contains unpublished material. All the authors have read and approved the manuscript and no ethical issues involved.

\section{Reference}

Aboel-Atta, A.M.I., 2009. Isozymes, RAPD and ISSR variation in Melilotusindica (L.) All. and M. siculus (Turra) BG Jacks. (Leguminosae). Acad. J. Plant Sci., 2: 113-118.

Andreeva, E., 1956. The content of Coumarinin sweet clover that is dried in different conditions. Scientific Proc. Series Crop Grow., 3: 46-48.

Baldridge, D.E. and R.G. Lohmiller, 1990. Montana Interagency Plant Materials Handbook. 1st Edn., Montana State University, Bozeman, pp: 337.

Berke, F. and B.A. Dornerni, 1955. Somhere mint takarmany novery. Allattengeztes, 4: 411-417.

Cong, J.M., F.Q. Chen and C.L. Sun, 2012. Study on comprehensive development of Metlilotussuavarolens L. J. Anhui Agric. Sci., 40: 2962-2963.

Deineko, E.V., 1983. The Creation of the Source Material of Sweet Clover Low in Coumarin. In: Collection of Scientific Papers of the Siberian Research Institute of Forages, Novosibirsk, pp: 90-101.

Dospekhov, B.A., 1973. Technique of Field Experience. 1st Edn., Kolos, Moscow, pp: 336.

Ghaderi-Far, F., J. Gherekhloo and M. Alimagham, 2010. Influence of environmental factors on seed germination and seedling emergence of yellow sweet clover (Melilotus officinalis). J. Planta Daninha, 28: 252-261. DOI: $10.1590 / \mathrm{S} 0100-83582010000300002$

Makkar, H.P.S., G. Tran, V. Heuze and P. Ankers, 2014. State-of-the-art on use of insects as animal feed. Anim. Feed Sci. Technol., 197: 1-33. DOI: 10.1016/j.anifeedsci.2014.07.008 
Meyer, D., 2005. Sweet clover production and management.

NAS, 1971. Atlas of Nutritional Data on United States and Canadian Feeds. 1st Edn., National Academy of Sciences, Washington, DC, pp: 772.

Ogle, D.G., J. Cane, F. Fink, L. St. John and M. Stannard et al., 2007. Plants for pollinators in the intermountain west. Idaho Technical Note No. 2. Natural Resources Conservation Service, Boise, Idaho.

PDACRK, 2012. The program for development of agribusiness complex in the Republic of Kazakhstan for 2013-2020 (AGRIBUSINESS - 2020). (2012).

Poptsov, A.V., 1976. Biology of Weed Solidity. 1st Edn., Nauka, Moscow, pp: 156.

Rogers, M.E., T.D. Colmer, K. Frost, D. Henry and D. Cornwall et al., 2008. Diversity in the genus melilotus for tolerance to salinity and waterlogging. Plant Soil, 304: 89-101. DOI: $10.1007 /$ s $11104-007-9523-y$

Rolston, P., 1978. Water impermeable seed dormancy. Botanical Rev., 44: 365-396. DOI: $10.1007 / \mathrm{BF} 02957854$

Sagalbekov, U.M., L.V. Berezin and L.V. Berezina, 1987. To the assessment of weed solidity of legumes. Breed. Seed Product., 2: 38-40.
Schipper, I.A., 1999. Sweet Clover Poisoning. In: Beef Cattle Handbook, North Dakota State University.

Sherif, E.A., 2009. Melilotus indicus (L.) all., a salttolerant wild leguminous herb with high potential for use as a forage crop in salt-affected soils. Flora Morphol. Distri. Funct. Ecol. Plants, 204: 737-746. DOI: $10.1016 /$ j.flora.2008.10.004

Stuezynski, E. and W. Mangalska, 1959. Wplen crynniv agrotechir nuch na za zavartoc cbialka unrowege wlokika i humaruny u notryebrillyn (Melilotus albus). Postepy Nauk. Roin., 5: 293-293.

Sullivan, J., 1992. Melilotusofficinalis. In fire effects information system [Online]. USDA, Forest Service, Rocky Mountain Research Station, Fire Sciences Laboratory.

Thornburg, A.A., 1981. Plant Materials for Use on Surface-Mined Lands in Arid and Semiarid Regions. 1st Edn., Soil Conservation Service, Washington, D.C., pp: 88.

Tomme, M.F., 1964. Feed of the USSR. 1st Edn., Kolos, Moscow, pp: 448.

VNII, 1985. Guidelines for Breeding of Perennial Grasses VNII Feed. 1st Edn., Moscow, pp: 188. 